\title{
Acoustic and Vibration Considerations for Advanced Microscopy Suites
}

\author{
Chris Papadimos*
}

* Papadimos Group, 818 Fifth Avenue, Suite 207, San Rafael, CA 94901

Transmitting electron microscopes (TEM) and other similar advanced microscopy instruments require very controlled, steady and low acoustic and vibration environments to allow utilization of the full range of their capabilities ${ }^{1,2,3,4}$. From recent engagements on a number of such projects in academic research institutions, the author, in collaboration with end users, instrument manufacturers and building designers, has developed a thorough understanding of what is required to attain suitable acoustic and vibration environmental conditions for rooms that house such instruments. The process starts by carrying out acoustic and vibration monitoring to assess proposed building sites, establishing required setbacks from existing sources of noise and vibration, developing space layouts to place TEM rooms optimally in the building, and developing appropriate structural support including foundation systems; together with detailed room considerations. The latter entails selection of partition types and mechanical equipment noise and vibration control, including room ventilation, ductwork and pipe work layout and details of wall penetrations to meet the required level of acoustic and vibration performance.

An inherent difficulty that has been encountered from the most basic to sophisticated facilities has been the lack of proper acknowledgement of the design challenges imposed by the stringent criteria for ultra-quiet laboratories. This is particularly complicated where these spaces are not adequately separated from conflicting uses often due to poor planning decisions or limited understanding about acoustic and vibration requirements for such instruments as typically found in manufacturer preinstallation manuals ${ }^{5,6}$. Resolution of strong disparities in the initial planning stage offers the potential for efficient design and close control of construction details, with the resulting cost savings and heightened assurance of a successful outcome. Refer to Table 1 that shows tasks to be completed for successful planning, design and construction for such spaces.

The information presented will be communicated through recent and ongoing case-studies for several examples that are considered state of the art designs for such research spaces. It is the intent to demonstrate that for such research spaces the entire building should be considered the instrument and treated as such during programming, planning, design and construction of facilities that house such advanced microscopy spaces.

\section{References}

[1] M. A. O’Keefe et al., Lab Design for High-Performance Electron Microscopy, Microscopy Today (May, 2004)

[2] J.H. Ferris et al., Design, Operation, Housing of Ultra-Stable, Low Temperature, Ultra-High Vacuum Scanning Tunneling Microscope, Review of Scientific Instruments, Volume 69 (2008)

[3] D.A. Muller et al., Room Design for High Performance Electron Microscopy (2006)

[4] L.F. Allard, Oak Ridge National Laboratory Advanced Microscopy Suites (2007)

[5] FEI Tools for Nanotech, Pre-Installation Manuals for Titan, Tecnai, Quanta, and Morgagni Instruments (2006 to 2009)

[6] JEOL Facilities Installation Requirements/Specifications, Various Instruments (2006 to 2009) 


\begin{tabular}{|c|c|c|c|c|}
\hline Site Selection & Programming & $\begin{array}{l}\text { Building } \\
\text { Planning }\end{array}$ & $\begin{array}{l}\text { Building } \\
\text { Design }\end{array}$ & $\begin{array}{l}\text { Construction } \\
\text { Review }\end{array}$ \\
\hline $\begin{array}{l}\text { Carry out } \\
\text { acoustic and } \\
\text { vibration } \\
\text { monitoring to } \\
\text { establish } \\
\text { baseline } \\
\text { conditions for } \\
\text { project site(s) }\end{array}$ & $\begin{array}{l}\text { Review with } \\
\text { users } \\
\text { instrument } \\
\text { manufacturer } \\
\text { acoustic and } \\
\text { vibration } \\
\text { specifications }\end{array}$ & $\begin{array}{l}\text { Review space } \\
\text { planning } \\
\text { throughout the } \\
\text { building }\end{array}$ & $\begin{array}{l}\text { Develop initial } \\
\text { design } \\
\text { guidelines and } \\
\text { finalize space } \\
\text { layouts for } \\
\text { TEM Suites }\end{array}$ & $\begin{array}{l}\text { Approve all } \\
\text { contractor } \\
\text { submittals for } \\
\text { compliance } \\
\text { with building } \\
\text { design }\end{array}$ \\
\hline \multirow[t]{4}{*}{$\begin{array}{l}\text { Use monitoring } \\
\text { data to assess } \\
\text { site and } \\
\text { exposure and } \\
\text { identify } \\
\text { appropriate } \\
\text { locations for } \\
\text { the TEM rooms }\end{array}$} & $\begin{array}{l}\text { Confirm design } \\
\text { goals in } \\
\text { consultation } \\
\text { with the users }\end{array}$ & $\begin{array}{l}\text { Review } \\
\text { locations for } \\
\text { elevator and } \\
\text { mechanical } \\
\text { shafts, loading } \\
\text { dock and other } \\
\text { areas of high } \\
\text { noise and } \\
\text { vibration levels }\end{array}$ & $\begin{array}{l}\text { Structural slab } \\
\text { design and } \\
\text { alternatives for } \\
\text { TEM rooms } \\
\text { including } \\
\text { foundations }\end{array}$ & $\begin{array}{l}\text { Perform } \\
\text { periodic site } \\
\text { visits to inspect } \\
\text { constructions } \\
\text { and issue } \\
\text { reports with } \\
\text { construction } \\
\text { deficiencies }\end{array}$ \\
\hline & & $\begin{array}{l}\text { Review and } \\
\text { finalize vertical } \\
\text { stacking in } \\
\text { terms of space } \\
\text { adjacencies }\end{array}$ & $\begin{array}{l}\text { Architectural } \\
\text { design for } \\
\text { partitions, } \\
\text { doors and } \\
\text { penetrations for } \\
\text { TEM rooms. }\end{array}$ & $\begin{array}{l}\text { Carry out } \\
\text { testing at key } \\
\text { construction } \\
\text { intervals to } \\
\text { ensure that } \\
\text { design goals are } \\
\text { met }\end{array}$ \\
\hline & & $\begin{array}{l}\text { Identify and } \\
\text { resolve any } \\
\text { remaining } \\
\text { constraints with } \\
\text { various design } \\
\text { disciplines }\end{array}$ & $\begin{array}{l}\text { Mechanical } \\
\text { systems design } \\
\text { and proper } \\
\text { equipment } \\
\text { selection and } \\
\text { ventilation } \\
\text { options }\end{array}$ & \\
\hline & & & $\begin{array}{l}\text { Coordinate with } \\
\text { users and } \\
\text { design team }\end{array}$ & \\
\hline
\end{tabular}

Table 1. Timeline for Planning, Design and Construction Sequence to be followed for Facility with TEM Spaces 